\title{
The Ethics of Obeying Judicial Orders in Flawed Societies
}

\author{
Robert C. Hughes
}

This is a post-peer-review, pre-copyedit version of an article published in Res Publica. The final authenticated version is available online at: http://dx.doi.org/10.1007/s11158-020-09471-3

Some accounts of the duty to obey the law argue that the duty is contingent on the legal system meeting high standards of legitimacy. For example, many democracy-based accounts of the duty rely on definitions of democracy that few, if any, of the societies conventionally labeled 'democracies' satisfy. ${ }^{1}$ If there is a moral duty to obey the law only in societies that are politically nearly ideal, there is no actual duty to obey the law. ${ }^{2}$ This is an uncomfortable conclusion. Other accounts of the duty to obey the law maintain, plausibly, that there is a defeasible duty to obey the law even in societies that fall short of the democratic ideal. ${ }^{3}$ These accounts can provide at most limited practical guidance without some method for determining when other duties (e.g. the duty to avoid injustice) outweigh the duty to obey the law. It would be desirable to have an account of the duty to obey the law that explains why there is sometimes, but not always, a duty to obey the law in flawed societies, and that provides concrete guidance about when the duty applies. ${ }^{4}$

${ }^{1}$ As Viehoff (2014, p. 342) writes, while defending of a democracy-based account of political obligation, 'Many (perhaps all) existing democratic states fall short' of even a 'quite minimal' standard of democratic procedure.

${ }^{2}$ For defense of a position with this structure, see Simmons (1979).

${ }^{3}$ Among these are the samaritan theory of Wellman (2005) and the plural subject theory of Gilbert (2006). Gilbert describe the obligation she defends as 'moral,' but she does say that the obligation provides a reason that should outweigh inclination.

${ }^{4}$ Raz (1986) offers an account of the duty to obey the law that is sensitive to non-ideal conditions. Though Raz's account includes a general discussion of the authority of states (pp. 70-109) and an explanation of the authority of a private arbitrator (pp. 41-42), Raz does not address the distinctive grounds for a public judiciary to have authority to resolve disputes. 
This article provides a part of such an account, focusing on one component of the duty to obey the law: the duty to obey judicial orders. I aim to show that there is a distinctive reason to respect judicial authority: it remedies objectionable inequalities of power that can arise in relationships between private persons. When two people have a dispute, they can have a problematic power imbalance if one of them can resolve the dispute unilaterally. ${ }^{5}$ To avoid objectionable inequalities of power between private persons, we need courts with public authority, i.e. authority that rightfully applies to everyone in a geographical jurisdiction, whether or not they consent to it.

This account of the duty to obey judicial authority addresses power imbalances that can arise as a result of good-faith moral disagreement between people who are generally competent at moral reasoning. These power imbalances are problematic even when the people involved are well-intentioned. Thus, the problem judicial authority solves arises in ideal theory; it arises in a hypothetical 'full compliance' society in which everyone is motivated by a sense of justice and competent (though fallible) at identifying what justice requires. ${ }^{6}$ That said, the problem also arises in less-than-ideal relationships, and less-than-ideal judiciaries can solve it. A judiciary can remedy problematic power inequalities, I argue, even when judges fall short of perfect impartiality. The duty to comply with judicial orders is compatible with some degree of bias among judges, e.g. with a widespread, unconscious inclination that makes judges somewhat

\footnotetext{
${ }^{5}$ The moral problem here does not always or even usually involve a risk that the dispute will be settled through violence. My account of the need for judicial authority is thus distinct from Greenberg's view that the need for judicial authority derives from "the overwhelming moral importance of having a way of ending disputes peacefully" (2014, p. 1315).

${ }^{6}$ The hypothetical assumption of full compliance is one way, but not the only way, in which ideal theory can be distinguished from non-ideal theory (Valentini 2012). 'Full compliance' can concern either individuals' or social institutions' compliance with justice (Simmons 2010, p. 11). The idealization here involves individuals' compliance.
} 
more likely to side with parties of a certain ethnic group. The duty does not apply, however, when a party can expect their arguments to a court to be effectively unheard. This may occur when a judge has expressed animus against a social group, when a judge has been bribed, when judges are subject to other forms of strong outside influence, or when judges hold ideological views rigidly. The duty to obey judicial decisions thus has limitations that are sometimes, but not always, relevant in severely non-ideal societies.

Because the grounds I identify for obeying judicial decisions concern fairness in individual relationships, not in society as a whole, a qualified duty to obey judicial decisions can exist even when injustice has compromised the duty to obey legislation. Many have argued that severe procedural or substantive injustice undermines the duty to obey the law. Shelby (2007), for instance, argues that certain types of racial injustice undermine the reciprocity-based moral obligation to comply with laws codifying civic obligations. (Racial injustice does not undermine universal, "natural" duties, some of which are codified in law.) Even when there are unjust inequalities in the overall social distribution of resources and power, the judiciary can help to address problematic relational inequalities. The duty to obey judicial decisions can thus survive systemic injustice that undermines any comprehensive duty to obey the law. To illustrate the role of public adjudication in promoting relational fairness, and to show that courts can play this role in a deeply non-ideal society, I shall focus on judicial orders concerning disputes about contracts for the exchange of services. Because these contracts do not involve transfers of property, the legitimacy of these contractual relationships does not rest on the legitimacy of the property system. The argument's application is not limited to this context, however. It applies to any sort of dispute in which it is objectionable for one party to be able to resolve the dispute through unilateral action. 
The account yields a nuanced conclusion about when there is a duty to obey in non-ideal societies. The parties to a dispute are morally required to comply with a judicial order in their dispute if all of the following conditions obtain: (1) the parties' dispute was in good faith, (2) the court's resolution of the dispute is more impartial than either party's own judgment, (3) the order does not call for violation of important natural duties or important artificial duties that the dutybearer incurred involuntarily, and (4) the primary aim of disobeying the court order would be to advance an ordinary, non-political project, not to call public attention to an injustice. This is admittedly a piecemeal account. A piecemeal account of the moral duty to obey the law is precisely what we should expect of an account that applies to severely non-ideal societies.

Though the account I offer is inspired by Kant's moral and political philosophy, it does not presuppose Kant's ethics, and it is not intended as an interpretation of Kant's (opaque) remarks on political obligation. ${ }^{7}$ The account does presuppose that respect for autonomy matters more than mere pleasure or preference-satisfaction. I acknowledge, however, that there may be core aspects of well-being that take priority over the component of autonomy my account discusses. My premise regarding the importance of autonomy thus should be acceptable to many non-utilitarians, not only to Kantians.

\section{Good-faith moral disagreement and moral conflict}

To explain the moral need for authoritative public adjudication in disputes about agreements, it is necessary to distinguish courts' authoritative function from their coercive function. Courts' authoritative function concerns their ability to determine what people's legal

\footnotetext{
${ }^{7}$ Kant's discussion of political obligation in non-ideal contexts focuses on the ethics of forcible rebellion, rather than on the ethics of ordinary law-breaking. For discussion of Kant's views on political obligation in "despotic" and "barbaric" societies, see Ripstein (2009).
} 
duties are. Court's coercive function concerns their ability to compel people to carry out their legal duties. The question whether and when people are ethically required to do what courts tell them to do primarily concerns courts' authoritative function. When does a court's determination of one's legal duties affect what one ethically ought to do? The ethical question is most salient when court's coercive power is insufficient to motivate compliance by itself.

To focus attention on courts' authoritative function, I will begin by considering disputes that result from a good faith moral disagreement between the parties to a contract. Of course disputes can arise for other reasons, such as a bad faith decision to breach a contract without justification. When people are unwilling to do what they know they ought to do, the coercive function of law is salient. When a dispute arises from good-faith disagreement about what is to be done, however, courts' ability (or inability) to clarify or to alter people's duties is more relevant. To further clarify the focus on courts' authoritative role rather than their coercive role, I shall limit the discussion initially to disputes between people who are generally competent moral reasoners. Competent moral reasoners can err, and they can disagree. Perhaps most obviously, they can disagree about how best to resolve conflicts between moral duties.

To see how moral disagreements can arise in the context of contractual agreements, it is necessary to understand the purposes agreements serve. When people make an agreement, one person makes the other a promise in exchange for something else. ${ }^{8}$ The promises involved here, like all promises, are more than mere statements about future intentions. By promising to do something, one gives up the moral power to change one's mind. ${ }^{9}$ There are two reasons for

\footnotetext{
${ }^{8}$ In legal language, I am discussing agreements in which a promise is offered in exchange for consideration. See Restatement (Second) of Contracts $\$ 71$. Whether the sorts of agreements that contract law addresses are best understood in terms of promises is controversial. For arguments that they are, see Fried (1981) and Shiffrin (2012).
}

${ }^{9}$ I draw this characterization of what a promise does from Shiffrin (2008). 
people to bind themselves morally in this way. First, people can have different interests or different views about what projects are worth pursuing. They thus might not be motivated to help each other in the absence of an agreement. An agreement to an exchange of services enables them both to pursue their projects more efficiently.

There is a subtler reason for people to make agreements when they already share a goal: agreements express respect for each other's autonomy. Suppose that Alice and Bob agree that there is a structure that needs to be built and that they should be the ones to build it. Alice could tell Bob that she is organizing the construction, and she could then start planning the project on the assumption that Bob will help. Given what she and Bob know about each other, of course he will be there to help when the project needs him. But it would be disrespectful of Alice to act in this way. She should instead ask for Bob's help. People have an interest in playing an active role in making decisions that affect their lives. A norm that people will not make plans for each other without first obtaining their consent is a way of expressing respect for this interest. The agreement protects Alice's autonomy as well as Bob's. Had Bob merely expressed an intention to help, Alice could justifiably predict that he will help. She is entitled to rely on his help only if he makes a promise and thus gives up the moral power to change his mind.

The next step is to show that people who are competent at moral reasoning can have good faith disputes about agreements they have made. There are several ways in which good faith disputes can arise. Most obviously, people can disagree about non-moral facts that are relevant to the performance of an agreement, but people can also have good-faith moral disagreements when the relevant facts are not in dispute. These disputes fall into two broad categories. First, the parties to an agreement might disagree about how to handle a moral conflict between the moral obligations associated with the contract and another moral requirement. People can reasonably 
disagree about what one should do when it is impossible to act without breaching a moral duty or obligation. $^{10}$

Moral conflicts concerning agreements arise when a new development makes the completion of the agreement interfere with the performance of another duty or obligation.

Consider an agreement to transport goods in exchange for something else of value-perhaps a financial payment, perhaps another service. Suppose that after the formation of the agreement, there is political instability at the intended destination, and rebels announce that they will seize vessels and aircraft arriving from abroad. ${ }^{11}$ The shipper who made this agreement does not own their own vessel; an investor has supplied it. Thus, if the shipper completes the trip and their vessel is seized, they will breach an obligation to manage the investor's property with due care. Furthermore, their return home will be substantially delayed, due to the seizure of their vessel and the reduced availability of other transportation. This delay will interfere with their performance of other moral obligations, including obligations to their family. The shipper faces conflicting obligations here. On the one hand, the shipper made a promise to the customer. On the other hand, the shipper has made a promise to the investor and has family obligations as well. If the transportation of these goods is very important to the customer and to other people at the destination (e.g., if scarce medicine is among the goods to be transported), the customer and the shipper might reasonably disagree about whether the importance of the promise to ship the goods outweighs the importance of the promise to care for the vessel or the family obligations that the

\footnotetext{
${ }^{10}$ The conflicting obligations may be merely pro tanto obligations. One or more possible resolutions of the conflict may be morally permissible even though it involves a breach of a pro tanto duty. I leave open the question whether they are dilemmas in the strong sense that every available action is morally impermissible.

${ }^{11}$ This hypothetical adds more detail to a hypothetical presented in Restatement (Second) of Contracts $\S \S 262$. The Restatement suggests that whether courts deem performance "infeasible" may depend on the social importance of the goods transported.
} 
shipper will be unable to perform as a result of the delay. The shipper does not question the validity of the promise to the customer. The question is about that promise's proper weight.

A second type of moral disagreement can arise when the parties disagree about whether their agreement gives one of the parties any moral obligation, even a pro tanto obligation, to perform some action. This disagreement could arise because of a good faith dispute about the interpretation of the agreement's terms. Or it could arise because they disagree in good faith about the moral validity of agreement. One possible source of legitimate disagreement about the validity of an agreement is the discovery that the agreement was based on a factual mistake. ${ }^{12}$

As an example, imagine that Phil is an architect with philanthropic motivations. He offers to help a social club construct a new building in exchange for a promise that some of the club's members will provide services to a charity Phil supports—a charity the club members would not otherwise have chosen to support. At the time Phil makes the agreement, he and the club's leaders both believe that the soil on the club's land is normal. As Phil starts the work, he discovers that there is an unusual problem with the soil on the club's land that will make construction a complicated undertaking. Though the construction is within the club's means, designing the building will require much more of Phil's time than he had predicted. He thinks that helping the club in exchange for the promised provision of services to his favored charity would be a poor use of his time. If the club wants the agreement to proceed on its original terms, must Phil finish the job? ${ }^{13}$ Phil and the club's leadership could disagree in good faith about

\footnotetext{
${ }^{12}$ In American law, under the Restatement rule for voidability of a contract due to mistake, if at the time of contract both parties make a mistake about a 'basic assumption on which the contract is made,' the contract is voidable unless the adversely affected party bears the risk of the mistake. The adversely affected party bears the risk if the parties agreed that he would bear the risk, if he knew that he had limited knowledge and decided to treat his knowledge as sufficient, or if the court finds that it is reasonable for him to bear the risk. Restatement (Second) of Contracts $\S \S 152,154$.

${ }^{13}$ The example is inspired by Stees v. Leonard, 20 Minn. 494 (1874).
} 
whether Phil is morally required to continue. If Phil does not continue, there may be a further disagreement about what compensation, if any, Phil owes to the club and its members for the services they have already provided in consideration for Phil's expected help to the club.

\section{Disputes and power}

Good-faith disputes can lead to problems in the distribution of power between the parties. Unless one party can demand that the other party accept a court's decision about how to resolve their dispute, each party is entitled to do what seems right to her. ${ }^{14}$ This entitlement often gives rise to a problematic inequality of power if a dispute concerns an agreement that involved an exchange, either of promises or of a promise for a present performance.

Suppose that A and B make an agreement, and a dispute arises about their agreement. What should the parties do? The first thing they ought to do is to discuss reasons for settling the disagreement one way or another. After discussion, they may find themselves in agreement — a happy outcome - but a good-faith dispute may persist after reasoned discussion. What should the parties do now? One of them could simply give in. Depending on the nature of the promise and the nature of the dispute, this may be the morally correct thing to do. For example, if it is very important to B that an ambiguous promise be performed according to her understanding, and performing in this way rather than according to his own understanding imposes only a trivial burden on A, A may have reasons of beneficence to accept B's interpretation even if it does not

\footnotetext{
${ }^{14}$ The inspiration for this thought comes from Kant's Doctrine of Right. Kant writes, 'Before a public lawful condition is established ... each [individual human being, people, or state] has its own right to do what seems right and good to it and not to be dependent upon another's opinion about this.' (Kant, Doctrine of Right, Ak. 6:312). Since Kant thinks that the existence of courts is what distinguishes a 'rightful condition' from the state of nature (Ak. 6:306), I take this to mean that if there are no courts, a party to a dispute about a matter of right may do whatever seems right to her.
} 
make sense to him. In other circumstances, however, A is not morally required simply to give in and perform as B expects.

The parties could agree to take their dispute to a third party, present their cases, and defer to her judgment. This could also be a happy outcome. However, there could be a good-faith dispute about who would be an appropriate arbitrator. If disagreement about this persists, neither party is morally required to give in to the opinion of the other party about who should judge the case. Now, suppose that there is no public judicial system with rightful authority; that is, there is no body whose decisions people are morally required to respect even if they do not explicitly consent to have their cases decided by this body. ${ }^{15}$ Then $\mathrm{A}$ is morally entitled to do what seems right and good to him after reasoned discussion with B.

If A's promise was part of an agreement with B and B has already performed her part of the agreement, this dispute will give rise to an inequality of power between them. A can still make decisions about what their agreement requires of him, but B can no longer make decisions about what the agreement requires of her. $\mathrm{A}$ is thus in a position of greater power. If his dispute with B proves intractable, he can resolve the disagreement in accordance with his own views about what is fair. Inequalities of power also arise, though less starkly, when a dispute arises during the first party's performance, or when the second party's performance partly overlaps with the first party's performance. If the first party has started performing her duties but has not completed them, she still has some influence over the outcome if the dispute proves intractable and both parties decide to do what seems right to them. But because the second party has thus far performed relatively fewer of his duties under the agreement, he has greater control over the

\footnotetext{
15 The difference between a public court and a private arbitrator is that a public court's rightful authority does not depend on the parties' consent to be governed by it.
} 
outcome. For this reason, an agreement whose terms appear to be fair and equal is not actually fair and equal if the parties' performance is not to be simultaneous and if authoritative adjudication of disputes is unavailable. The party whose most important duties under the agreement are to take place later will have greater power if any disputes about the agreement arise after the other party's performance has begun.

It is important to be clear about why this power inequality is problematic. The moral problem here does not stem merely from the risk that a unilateral resolution of the dispute will benefit one party's welfare at the expense of the other party's. There is a moral problem with unilateral resolution of disputes even if the parties value each other's welfare as much as they value their own. People's interests are not limited to their interests in advancing their own welfare. People also have a broader interest in actively pursuing their conceptions of the good. ${ }^{16}$ If one party to a dispute gets to resolve the dispute however he sees fit, the other party loses the opportunity to pursue her conception of the good in the context of the dispute. This is a loss to her even if it does not involve a loss of welfare in the ordinary sense. ${ }^{17}$ Recall the example of Phil, the architect who agrees to help a social club design a new building in exchange for a contribution of work or services to Phil's favorite charity. If Phil and the club have a dispute after Phil presents his design, the club may decide that Phil did not perform as expected and that the club is not obligated to contribute as much as they agreed to provide. The club members' failure to fulfill their side of the bargain would not be a major setback to Phil's welfare, since Phil's

\footnotetext{
${ }^{16}$ As Rawls explains, one's conception of the good is not the same as one's conception of one's welfare. People's conceptions of the good can be altruistic, and benevolent people's views about what goods are to be pursued can differ greatly (Rawls 1971, p. 129).

${ }^{17}$ For some reasons not to count the satisfaction of impersonal preferences as a component of welfare, see Dworkin (2000, pp. 21-28).
} 
purpose in making this bargain was altruistic. It would be a major setback to Phil's pursuit of his conception of the good.

There is another reason it is morally problematic for one party simply to act on her own view about what is fair in the face of an intractable dispute. The other party will not get to play an active role in determining the outcome of an important aspect of their interaction. Part of the point of the practice of making agreements is to enable people to have interactions in which each person involved plays an active role in determining the terms of the interaction. At the very least, each person gets to say yes or no. Now, if one of the parties to an agreement is entitled to decide the resolution of a good faith dispute about the terms, the other party does not get to play an active role in shaping the aspect of the agreement that the dispute concerns. Since both parties have an interest in being able to shape the terms of their interaction, it is objectionable for one party to have exclusive control over the outcome of a dispute.

\section{Adjudication as the unique remedy}

There is only one adequate remedy for the inequality of power that can arise when the parties to an agreement have a good faith dispute. That is for a public judiciary to be able to settle disputes authoritatively when the parties cannot agree either about the substance of their dispute or about which third party would be an appropriate arbitrator. If there is a public judiciary with this sort of authority - authority that is morally binding on everyone in a geographic jurisdiction, whether or not individuals consent to it - then one party to a dispute can rightly demand that the other accept a court's decision about how the dispute should be resolved. Neither party will be entitled simply to do what seems right to her. Once one party has taken the dispute to court, both parties morally must comply with the court's judgment. The decision will 
bind both parties even if one party chooses not to participate in litigation and the court issues a default judgment.

The option of taking an intractable dispute to a court for authoritative resolution would solve both problems that arise when parties to a dispute are entitled to do whatever they think right. Regarding the first problem, if the court gives both parties' arguments a fair hearing, both parties have a fair chance to receive a judgment that enables them to advance their conception of the good. So if two people make an agreement in which one person is to perform her part of the agreement after the other person has completed his, the party to perform second will not have a greater opportunity to pursue his conception of the good in case of dispute simply because his performance was to be later. Regarding the second problem, if the court's decision is rationally responsive to both parties' arguments, it gives both parties an equal opportunity to play an active role in determining the structure of their interaction with each other. The timing of the parties' performance does not give one party more opportunity to influence the structure and outcome of their interaction.

To see why public judicial authority is the only way of adequately addressing the power inequality that can arise between the parties to a contract dispute, consider three alternatives: legislating away potential sources of disagreement, relying on private arbitration, and settling disputes by the toss of a 'fair' coin. One might think that morally problematic disputes can be largely avoided by having a legislature make general rules regarding the issues that commonly arise when people have disputes about their agreements. These rules would give people guidance about what to do in cases in which universal (or 'natural') moral requirements do not provide clear guidance. It is true that legislation can reduce the number of disputes that occur. No matter how sophisticated the rules are, and no matter how clearly they are articulated, they will not be 
able fully to address every possible dispute that will arise. It is impossible to produce bright-line rules that can be applied mechanically to every possible situation.

One might think that the inequality disputes produce can always be avoided by agreeing to arbitration in advance. People who are unable to agree on an arbitrator at the time of a dispute may have been able to agree on an arbitrator if they had considered the possibility when they made their agreement. If people making an agreement are thoughtful about the morality of promising, they will be aware in advance of the possibility of dispute and the inequality of power it could generate in the absence of authoritative adjudication. Recognizing this need, they will agree to arbitration at the time they make the agreement. There are two reasons not to require people to commit to arbitration at the time they make their agreement if they want authoritative resolution of disputes to be available. First, this requirement may cause people to refrain from making worthwhile agreements. People who can agree about the substance of an agreement may be unable to agree who should be the arbitrator if a dispute arises. Thinking about the possibility of dispute may also give people cold feet about a worthwhile transaction.

A deeper reason for having public adjudication, rather than requiring people who may want adjudication to agree in advance on a private party to arbitrate, is that an agreement to go to an arbitrator may itself be subject to good faith dispute. ${ }^{18}$ For instance, the parties to an agreement may choose an arbitrator based on the incorrect belief that this person is a competent decision-maker who has relevant special experience. On discovering that the agreed-on arbitrator lacks either the expertise or the general reasoning power the parties both thought he had, the parties may legitimately disagree about whether their mistake should void their promise to let this person settle disputes for them. So the ability to opt in to arbitration does not adequately

\footnotetext{
${ }^{18}$ [Acknowledgment omitted for blind review.]
} 
address the inequalities that good-faith disputes can create. There needs to be a norm requiring disputing parties to accept public adjudication if they cannot agree either on a resolution or a private arbitrator. If a court finds the arbitration clause valid and sends the parties to arbitration, the court plays a crucial role in the resolution of the dispute. Its act is an exercise of authority, not a disclaimer of it.

One might think there is a third possibility. Instead of a norm requiring disputing parties to accept the decision of a court, perhaps there could be a norm requiring disputing parties to accept the outcome of a coin toss. This would clearly be a terrible way of resolving disputes between dishonest people. Dishonest disputants would propose resolutions to the dispute that they do not really think are fair but that would be greatly to their advantage. When a dispute results from a sincere, good faith disagreement, a coin toss may seem to be a good way of resolving the dispute. Honest people would not propose resolutions they do not sincerely regard as fair. If both parties present resolutions they sincerely consider fair, a coin toss may be as accurate a method of resolving disputes as submitting disputes to a judge. A judge (or an arbitrator) faced with competently, sincerely reasoned cases for each side may have no better than a fifty-fifty chance of getting the correct answer to the moral question at hand. Moreover, it appears that the coin toss addresses at least one of the two problems arising from the inequality of power disputes can cause in the absence of authoritative adjudication. By giving each of the parties an exactly equal chance to prevail, it ensures that the dispute does not give either party a greater opportunity to pursue her conception of the good.

The problem with resolving a good faith dispute with a coin toss is that it guarantees that one of the parties to the dispute will be denied the opportunity to exercise agency in shaping the parties' interaction. Whichever party wins the toss will get to set the terms of their interaction; 
the other party will be shut out. When a judge (or an arbitrator) decides a dispute, by contrast, the judge's decision is supposed to be rationally responsive to the positions of both parties. Because judges are expected to be responsive to both parties' reasoning, both parties can exercise agency over their relationship in attempting to persuade the court. A court may choose to accept a position that is a compromise between the positions the two parties advocate. Even if the court completely accepts one of the parties' positions and rejects the other's, the losing party is not completely shut out of the process of decision-making as he would have been if the decision had been made by a coin toss or some other non-rational procedure. His arguments played a role in the judge's reasoning about the case even if they were ultimately rejected.

\section{A conditional duty to obey}

If judicial authority is uniquely able to resolve the problematic power imbalances that disputes can produce, there is a straightforward argument for a pro tanto duty to obey judicial decisions. There is a pro tanto moral duty to avoid objectionable power imbalances. If the only way for someone involved in a dispute to avoid an objectionable power imbalance is to yield to a court decision, one has a pro tanto duty to do so. When is the pro tanto duty an all-thingsconsidered duty? Mere preference does not outweigh pro tanto duties, so the mere fact that a party strongly prefers an outcome will not justify violating a court's contrary ruling. Only another, conflicting duty can outweigh the pro tanto duty to accept the court's ruling as binding.

This brief argument for a pro tanto duty to obey judicial decisions is potentially actionguiding when court rulings concern the existence or non-existence of a contractual obligation. It is not action-guiding when a court ruling concerns the proper resolution of a conflict between two pro tanto duties. Adding one more pro tanto duty into the mix does not necessarily alter the balance of reasons in favor of the course of action the court demands. To show that court 
decisions can help resolve moral conflicts, it is necessary to show that the value of equal power relationships takes precedence over other duties with which the court's decision conflicts.

There are two sorts of duties that could conflict with a court ruling. First, a court ruling could conflict with a natural duty, that is, a duty whose existence does not derive from human choice. For instance, if a court's order of specific performance would require the party subject to it to act in a way that puts an innocent third party in grave physical danger, the natural duty to respect others' physical safety would conflict with the pro tanto duty to obey the court's order. A weighty natural duty, such as the duty to respect others' safety, could well take precedence over the duty to respect the court's order (which, again, derives from the duty to avoid undue imbalances of power).

Second, a court's order can conflict with an artificial duty, a duty whose existence derives at least in part from human choice. Among these are duties created by a voluntary choice of the person who bears the duty, such as the duties or obligations created by a promise or the duties of a chosen occupation. Artificial duties also include duties imposed by political or social institutions with legitimate authority, such as legislatures acting within their rightful limits. Natural duties limit voluntarily chosen artificial duties. A promise to violate a natural duty (e.g. to commit an act of wrongful violence) is morally void; it gives the promisor no moral duty or obligation to perform (Shiffrin 2011). Natural duties likewise constrain the moral obligations one can voluntarily take on through choosing an occupation or accepting another social role. The duty to avoid objectionable power imbalances is a natural duty. It thus constrains the possible content of valid promises and other voluntarily chosen artificial duties. If it is possible to maintain a fair distribution of power in contractual relationships (or other relationships) if and only if we accept judicial resolution of conflicts, then we cannot have voluntarily chosen 
artificial duties that conflict with the duty to comply with judicial orders resolving conflicts. Though the latter duty is artificial, it derives from a natural duty and is the only way to fulfill it. If a voluntarily chosen artificial duty appears to conflict with the pro tanto duty to obey judicial orders, we should either reinterpret the artificial duty so that there is no conflict or acknowledge that the judicial order takes precedence. ${ }^{19}$ Matters are somewhat more complicated when a judicial order conflicts with artificial duties unchosen by the bearer of these duties. For instance, perhaps a court order could conflict with duties that derive from the law of property and tax.

Such conflicts presumably arise only if the court lacks the power to alter these duties and fails to take them into account.

One might worry that there is a self-regarding natural duty to insist on one's view about the proper resolution of a moral disagreement. ${ }^{20} \mathrm{I}$ do not think there could be a self-regarding duty to insist on one's own view about a contract dispute in the face of a contrary judicial decision. The value of the rights and duties associated with agreements derives at least in part from the voluntary nature of the agreement; the agreement reflects the will of the parties. When conflicts arise concerning agreements, the resolution cannot fully reflect both parties' will. To the extent it is possible to preserve the mutually voluntary nature of a relationship by giving both parties' reasoning an influence over the outcome when their wills diverge, it is desirable to do so. The value of preserving equality between the parties thus outweighs the value of standing one's ground — even when one's own view about the agreement is correct.

19

${ }^{20} \mathrm{My}$ argument does not rest on the idea of self-regarding duties, but if we deny that there are self-regarding duties, it will be necessary to add a qualification to the duty to obey court orders: some self-interested concerns override the duty. As Timmerman (2006) points out, including self-regarding duties in ethics is necessary to sustain the view that ethical duties are overriding. 
So there is a conditional duty to obey court orders concerning the resolution of contract disputes. One should obey a court decision if (a) the dispute was in good faith, based on a genuine disagreement, (b) the court order does not conflict with natural duties, e.g. the duty to respect third parties' physical safety, (c) the court order does not conflict with artificial duties that the bearer did not choose and that the court cannot modify, and (d) the court's decisionmaking process takes both parties' arguments into account. When these conditions are met, yielding to the court's decision rather than insisting on one's own view is necessary to avoid an unfair imbalance of power between oneself and the other party. It is objectionable for one of the parties to a good-faith dispute to claim the right to resolve the dispute unilaterally.

\section{Obeying decisions by an unjust judiciary}

Does this account of the duty to obey judicial decisions apply to real-world courts? In some countries - there is no need here to name names — the judicial appointment process is unfair or inappropriately politicized. In many countries, courts have a history of making decisions that tend to disfavor members of unfairly disadvantaged social groups. Is one ethically required to obey judicial decisions under these conditions?

To answer this question, it is necessary to understand what conditions a judiciary must satisfy if it is to resolve the problematic power imbalances that disputes can produce. The simple answer is that judges and juries must be impartial, but this answer is too quick. One definition of impartiality is Gert's: 'A is impartial in respect $R$ with regard to group $G$ if and only if A's actions in respect $\mathrm{R}$ are not influenced at all by which member(s) of $\mathrm{G}$ benefit or are harmed by these actions.' (Gert 1995, p. 104) This definition of impartiality is in one way too broad and in another too narrow. It is too broad because it implies that if a decision-maker has even the slightest inclination to favor one of the parties, perhaps an entirely subconscious inclination, this 
inclination taints the decision with partiality. This definition of impartiality is too narrow because it implies that in certain types of disputes, the parties themselves may be impartial. Consider a dispute about an agreement made for charitable purposes. The parties are not motivated by the hope of benefit or the fear of harm to themselves. Gert's definition implies that they are therefore impartial. Yet it is still unfair to let one of the two parties (e.g. the party to perform second) to resolve the dispute unilaterally. Both parties are entitled to have a rational influence over the outcome.

Of course, it would be ideal for judges and juries to be altogether free of any inclination to favor some plaintiffs or defendants for any reason other than the merits of their arguments. This ideal is probably unattainable. There is evidence that many people have implicit biasesunconscious attitudes and stereotypes that are not accessible to introspection-and that jurors and judges in both civil and criminal cases are sometimes influenced by implicit biases (Kang et al. 2012). Though there may be ways to reduce implicit bias or its effects on decision-making, the aspiration to eliminate unconscious bias altogether is utopian.

The duty to obey court rulings does not presuppose that judges and juries meet this high and probably unattainable ideal. Rather, the duty to obey turns on the question whether the relationship between the parties becomes fairer if they both accept the court's resolution of their dispute, whether or not they agree with it. Again, it is relationally unfair for one of the parties to a dispute to claim a right to resolve the dispute unilaterally if the parties cannot reach an agreement. Courts can contribute to relational fairness if they are unbiased enough that people on either side of a dispute can expect their arguments to the court to receive a meaningful hearing. The parties must have a realistic expectation that the court will take their reasoning into account, either by accepting it, by giving good reasons why they do not accept it, or by partially accepting 
it as part of a reasoned compromise. Note that relational unfairness and distributive unfairness do not always go together. It is possible for one of the victims of an overall distributive injustice to be the beneficiary or the perpetrator of an unfair inequality in a two-party relationship. For example, a member of a socially disadvantaged group could be the party to perform second in an agreement for an exchange of services. This person will have the unfair opportunity unilaterally to resolve disputes concerning that agreement if no authoritative adjudication of disputes is available. $^{21}$

Is there, then, a duty to obey court rulings in a society where the courts have a history of favoring some social groups over others? The answer depends on the specific form this unfairness takes. If courts always or almost always favor members of a certain group over others, and a member of the favored group has a contract dispute with a member of a disfavored group, going to court will not resolve the relational inequality between the parties. The same is true if a particular judge always or almost always favors members of a certain group, or if the judge has openly expressed animus against a group. Turning the dispute over to a court that will reliably favor the other party merely shifts unilateral dispute-resolving power from one party to the other. Matters are different if judges and jurors are free from explicit bias but are influenced by subtle but statistically significant forms of implicit bias favoring a certain group. The pattern is unjust, but members of less favored groups still have a realistic hope that their arguments will get a meaningful hearing. In these conditions, going before a court and accepting the outcome does address a power imbalance. Both parties get their arguments heard; both parties rationally influence the outcome; neither party's arguments automatically carry the day.

\footnotetext{
${ }^{21}$ Compare Wertheimer's (1999, pp. 4-5, 267-269) example of the working-class truck driver who demands an exorbitant fee to rescue a wealthier driver whose car is stuck in the snow.
} 
One might object that if courts or individual judges have a pattern of favoring some groups over others - even a less severe pattern, i.e., one that is compatible with giving meaningful hearings to arguments presented by disfavored groups - there is a natural duty of justice to disregard these courts' or these judges' decisions. Perhaps there is a duty of justice to express public condemnation of patterns in judicial decision-making or to try to bring about change in these unjust patterns. Perhaps civil disobedience is a permissible or even a required manner of expressing protest. But the natural duty of justice would only justify disobedience motivated either by the aim of expressing public condemnation of an unjust pattern, the aim of changing the pattern, or both. A natural duty of justice would not justify disobedience with other motives, such as the inconvenience of complying or disapproval of an individual decision.

One might worry about situations in which the parties to a dispute disagree about whether courts or individual judges (or jurors) are too biased to resolve disputes with rightful authority. Suppose A, the party to perform second in a contract and a member of a disadvantaged minority group, believes that the courts are so biased that their decisions are not binding. Suppose B, who is not a member of that minority group, acknowledges that many judges and jurors have unconscious biases but believes that courts can nonetheless be expected to give all arguments from all parties a reasoned hearing. Is B entitled to demand that A accept the court's decision? The answer depends on what A and B are justified in believing, based on the evidence available to them. If they should believe that the courts are sufficiently unbiased to make morally binding decisions, they should both act accordingly. If they should believe that the courts are too biased to resolve disputes in a way that gives both parties' arguments a meaningful hearing, they should not take their dispute to court. They should instead acknowledge that no fair resolution is possible if they cannot agree either on an outcome or on a private arbitrator. (Tossing a coin 
would not yield a fair resolution, for reasons discussed above, though it could be less unfair than some alternatives.) The dispute will be irreconcilable in a different way if A and B have different life experiences that justify them in having different beliefs about the courts' ability to resolve disputes fairly. Then A might be justified in refusing to accept the courts' authority as legitimate, and B might be justified in criticizing A for taking this stand.

So, some forms of bias among judges and jurors toward socially disadvantaged groups do undermine the moral duty to obey judicial decisions. Other forms of bias do not. The same analysis applies to judicial inclinations to favor certain ideological positions. If judges were required to have no partisan affiliation and no political beliefs, as a condition on the legitimacy of their decisions, hardly any judicial decisions would be legitimate. A pattern of favoring some ideological positions over others does not undermine the duty to obey judicial decisions, provided that people with less-often-favored positions can reasonably expect their arguments to receive a meaningful hearing. If, on the other hand, judges are publicly known to have rigid ideological convictions that prevent them from even considering views they do not share, the duty to obey court decisions will be undermined. If some people expect courts simply to write off their arguments without due consideration, they cannot take disputes before courts expecting court decisions to reflect both their reasoning and the other party's. Courts thus cannot perform their equalizing function.

What about injustice in the judicial appointments process? Here again, the question is whether two parties can take a dispute to court expecting both parties' arguments to have a rational influence over the outcome. The answer is no if judges are beholden to the people who put them in power or the people who keep them in power (be it the executive branch, the ruling party, or the electorate) to such a degree that they cannot freely exercise their own judgment. 
That said, some grave injustices in the appointments process are compatible with a duty not to disobey judicial decisions for motives other than protest. Suppose, for instance, that a judge is widely and accurately rumored to have obtained her office by making campaign contributions that are not, legally speaking, bribes, but that do constitute a morally problematic form of influence. ${ }^{22}$ That history justifies protest, and it arguably justifies disobedience of the judge's decisions done with the aim of drawing attention to this injustice. It does not justify disobedience done with other aims, provided that the judge appears to have both the ability and the willingness to give due consideration to arguments presented.

A last potential obstacle to the judiciary's performance of its power-equalizing function is unequal access to legal representation. The judiciary can still perform its power-equalizing function even if parties to a case lack access to equally skilled representation. A party who has an inferior attorney or who litigates pro se may be less likely to receive a favorable hearing. A significant chance that both parties' arguments will be understood and will influence the outcome is better than unilateral resolution of a dispute. Unilateral resolution of a dispute is what will happen if one of the parties disobeys a judicial order with impunity.

\section{The continuity of ideal and non-ideal theory}

Some accounts of the duty to obey the law suggest that ideal theory and non-ideal theory are discontinuous. On these views, the moral duty to obey is greatly weakened or altogether absent in a society that falls short of ideal democracy. This article's argument for a moral duty to obey judicial decisions shows that ideal theory and non-ideal theory are in fact continuous. The

\footnotetext{
22 Judicial misconduct that violates important laws, such as laws against bribery, could undermine a judge's moral standing to act as a public official. So could judicial violations of generally accepted professional norms, e.g. a norm against making decisions under the influence of alcohol.
} 
ground of the duty to obey judicial decisions in contract cases is the judiciary's ability to address objectionable power imbalances in contractual relationships between private persons. These unfair power imbalances can arise in any society that lacks authoritative public adjudication of disputes. Courts can address this relational unfairness even if they display a noticeable degree of bias, either against population groups or against ideological positions, and even if the judicial appointments process is unfair. Other forms of systematic unfairness, such as bias that altogether prevents judges or juries from giving due consideration to arguments presented, can undermine the duty to obey judicial decisions. So can judicial orders to violate important natural duties. But the moral duty to obey judicial decisions can survive substantial departures from ideal fairness.

\section{Acknowledgments}

My thanks to Allyn Fives and Kei Hiruta for their invitation to contribute to this special issue and for their advice on revising the manuscript. I am grateful to Brian Berkey, Joshua Dienstag, Barbara Herman, Matthew King, Sarah Light, Calvin Normore, Amy Sepinwall, Seana Valentine Shiffrin, Alan Strudler, the members of the Wharton LGST junior workshop collectively, and an audience at the Midwest Political Science Association Annual National Conference for their helpful comments on earlier versions of this paper.

\section{References}

American Law Institute. Restatement (Second) of Contracts.

Dworkin, Ronald. 2000. Sovereign Virtue. Cambridge, Mass.: Harvard University Press.

Fried, Charles. 1981. Contract as Promise. Cambridge, Mass.: Harvard University Press.

Gert, Bernard. 1995. Moral impartiality. Midwest Studies in Philosophy 20: 102-128.

Greenberg, Mark. 2014. The moral impact theory of law. The Yale Law Journal 123:1288-1342. 
Kant, Immanuel. 1996 [1797]. Doctrine of Right. In Practical Philosophy, ed. and trans. Mary J. Gregor. Cambridge: Cambridge University Press.

Kang, Jerry, Mark Bennett, Devon Carbado, Pam Casey \& Justin Levinson. 2012. Implicit bias in the courtroom, UCLA Law Review 59: 1124-1186.

Rawls, John. 1971. A Theory of Justice. Cambridge, Mass.: Harvard University Press.

Raz, Joseph. 1986. The Morality of Freedom. Oxford: Oxford University Press.

Ripstein, Arthur. 2009. Force and Freedom. Cambridge, Mass.: Harvard University Press.

Shelby, Tommie. 2007. Justice, deviance, and the dark ghetto. Philosophy \& Public Affairs 35: 126-160.

Shiffrin, Seana Valentine. 2008. Promising, intimate relationships, and conventionalism. Philosophical Review 117: 481-524.

Shiffrin, Seana Valentine. 2011. Immoral, conflicting and redundant promises. In R. Jay Wallace, Rahul Kumar, and Samuel Freeman (eds.), Reasons and Recognition: Essays on the Philosophy of T.M. Scanlon. Oxford: Oxford University Press.

Shiffrin, Seana Valentine. 2012. Is contract a promise? In The Routledge Companion to Philosophy of Contract Law, ed. Andrei Marmor. New York: Routledge 2012.

Simmons, A. John. 1979. Moral Principles and Political Obligations. Princeton: Princeton University Press.

Simmons, A. John. 2010. Ideal and non-ideal theory. Philosophy \& Public Affairs 38:536.

Timmerman, Jens. 2006. Kantian duties to the self, explained and defended. Philosophy $81(3): 505-530$.

Valentini, Laura, 2012. Ideal vs. non-ideal theory: A conceptual map. Philosophy Compass 7/9: 654-664.

Viehoff, Daniel. 2014. Democratic equality and political authority. Philosophy \& Public Affairs 42: 337-375.

Wellman, Christopher. 2005. Samaritanism and the Duty to Obey the Law. In Christopher Wellman and John Simmons, Is There a Duty to Obey the Law? Cambridge, UK: Cambridge University Press, 2005.

Wertheimer, Alan. 1996. Exploitation. Princeton: Princeton University Press. 